綜 説 (Review Article) : 膜 (MEMBRANE), 15 (6), 296-303 (1990)

\title{
薬物の皮膚透過
}

\author{
東 條 角 治
}

九州工業大学情報工学部 生物化学システム工学科 雪 820 飯塚市川津 680-4

\section{Penetration of drugs through the skin}

\begin{abstract}
Kakuji Tojo
Department of Biochemical Science and Engineering, School of Computer

Science and Systems Eugineering.

Kyushu Institute of Technology, Iizuka 820, Japan
\end{abstract}

A variety of drugs may be administered through intact skin to reach the systemic circulation ins ufficient quantity if we overcome barrier functions of the skin against the entry of xenobiotics.

This paper reviews effects of various factors to enhance the penetration of drugs through the skin.

Key words : skin, percutaneous absorption, transdermal drug delivery, iontophoretic drug delivery, prodrug.

\section{1. はじめに}

薬物を皮膚から全身の標的組織へ送達する経皮吸収治 療システムは，手軽で効果的なドラッグデリバリーシス テムとして大きく期待されている. しかし現状では, 皮 膚とくに角質層のバリアー機能のため, 治療に有効な量 の薬物を皮膚を介して体内に送達することは容易でな い. 薬物の皮膚透過抵抗を低減するための種々の透過促 進法が提案されている。透過促進剂（エンハンサーある いはプロモーター) を用いる化学的促進法, 電場, 超音 波, 温度場, 角質層ストリッピング法などの物理的促進 法, および酵素反応・プロドラッグ法* に代表される生 化学的促進法など積極的に研究されている.

本稿では，薬物の皮膚透過におよぼす種々の透過促進 因子の影響を検討した, in vitro 実験結果を紹介する.

\section{In Vitro 皮膚透過実験}

種々の薬物の in vitro 皮膚透過実験を水平型拡散セ ル1（図 1）あるいは，たて型拡散セル"（図 2）に，動 物モデル（ヘアレスマウス）の腹部の皮膚をとり付け， 種々の操作条件下で行った. 透過量の時間変化を測定し, 定常状態での透過速度および時間遅れを求めた。ここで 検討した因子は次のとおりである.

(1) 透過促進剤の影響

（2）角質層ストリッピングの影響

(3) 温度の影響

（4）電場の影響

(5) 超音波の影響

（6）酵素分解反応(プロドラッグ）の影響

なお，透過実験は，とくに記述のない限り $37^{\circ} \mathrm{C}$ (一 定）で行った.

\section{3. 透過促進剂の影響}

*高い親水性や不安定なため皮䖉透過の困難な薬物を化学修飾によ り, 親油性を高めたり安定性を增大し, 皮䖉 (角質層) 透過後, 皮膚内に分布する酵素の作用で, もとの薬物に変換する透過促進 法をプロドラッグ法という。
ロゲステロンの皮膚透過におよぼす促進剤 
Azone の影響を示す ${ }^{2)}$ ．透過実験は，水平型拡散セル （図 1）のドナー側にシリコンオイルの薬物飽和液を，ま たレセプター側には，40\% PEG 400 水溶液を満たした.

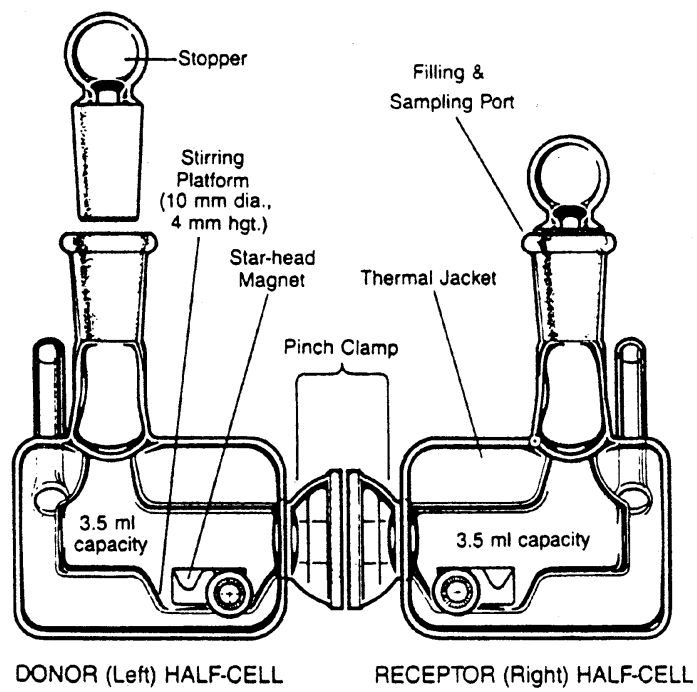

図 1. 皮膚透過実験用 in vitro 装置（水平型拡散 セル)
膜 (MEMBRANE), Vol. 15 No. 6 (1990)

297

PEG 400 溶液はレセプター液でのシンク条件を保つた め用いた ${ }^{3)}$ 。 ドナー液中の促進剂濃度を $0 \sim 5 \%(\mathrm{w} / \mathrm{w})$ の範囲で変化させた場合, 定常状態（10２5 時間）の 透過速度は約 3 倍増大した. 図には示していないが，5 $\%$ の Azone 濃度で角質層の透過バリアーが完全に取除 かれ，角質層を取除いた皮膚（Viable skin）で Azone を含まない場合の透過速度にほぼ一致した．定常状態の 直線部分を時間軸へ外押して得た時間遅れは, Azone 濃度にほとんど影響されないここが認められた。

同程度の分子量 $(200 \sim 3 \curvearrowleft$ U) 之類似の分子形状（ステ

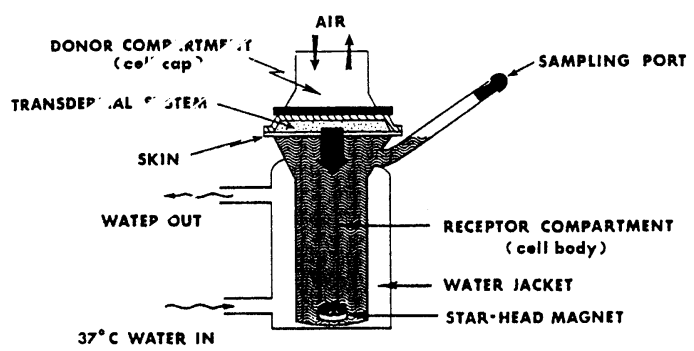

図 2. 皮膚透過実験用 in vitro 装置（たて型拡散 セル）

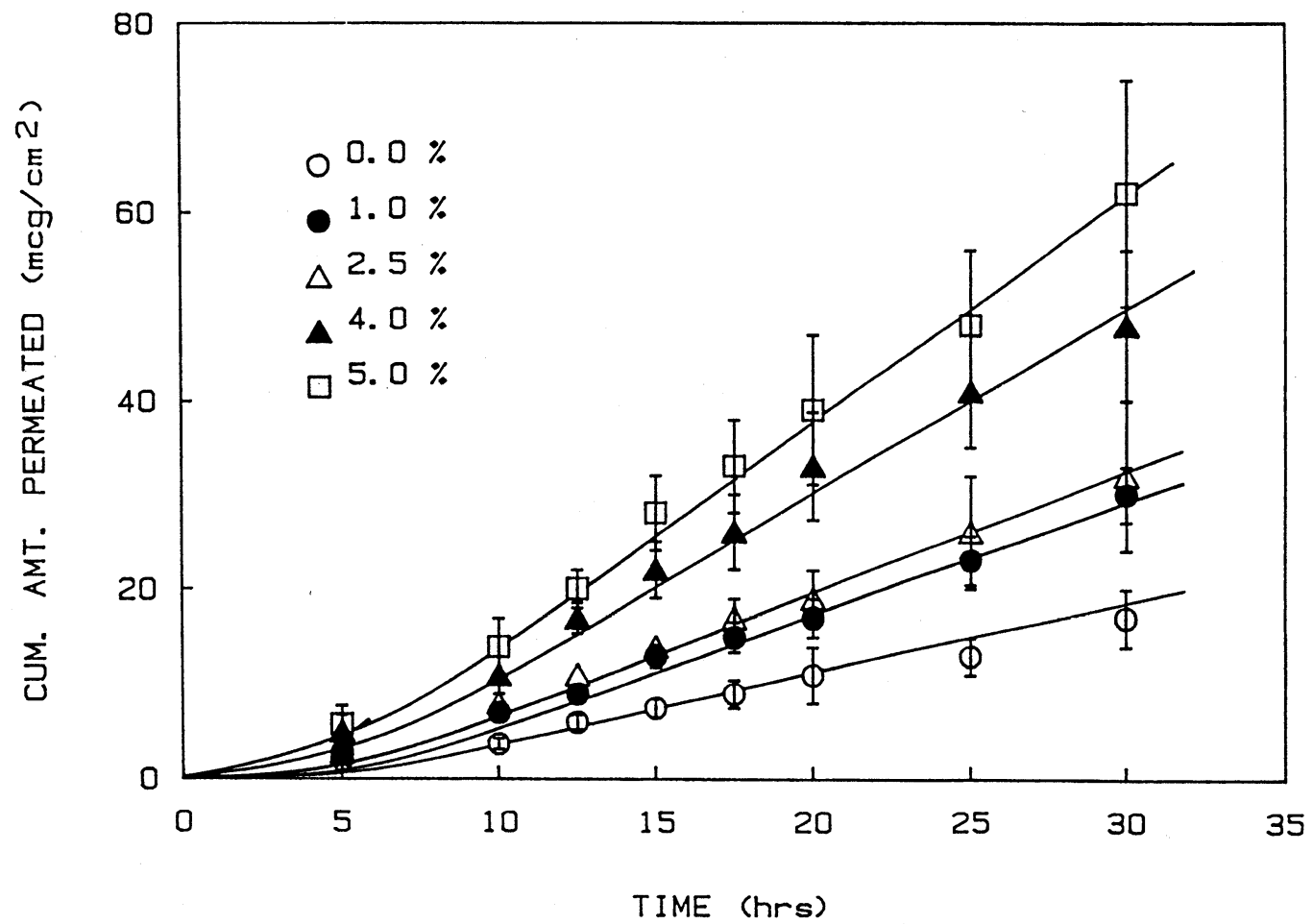

図 3. Progesterone の皮膚透過プロフィルにおよぼす透過促進剤 Azone の影響 $(\mathrm{mcg}=\mu \mathrm{g})$ 


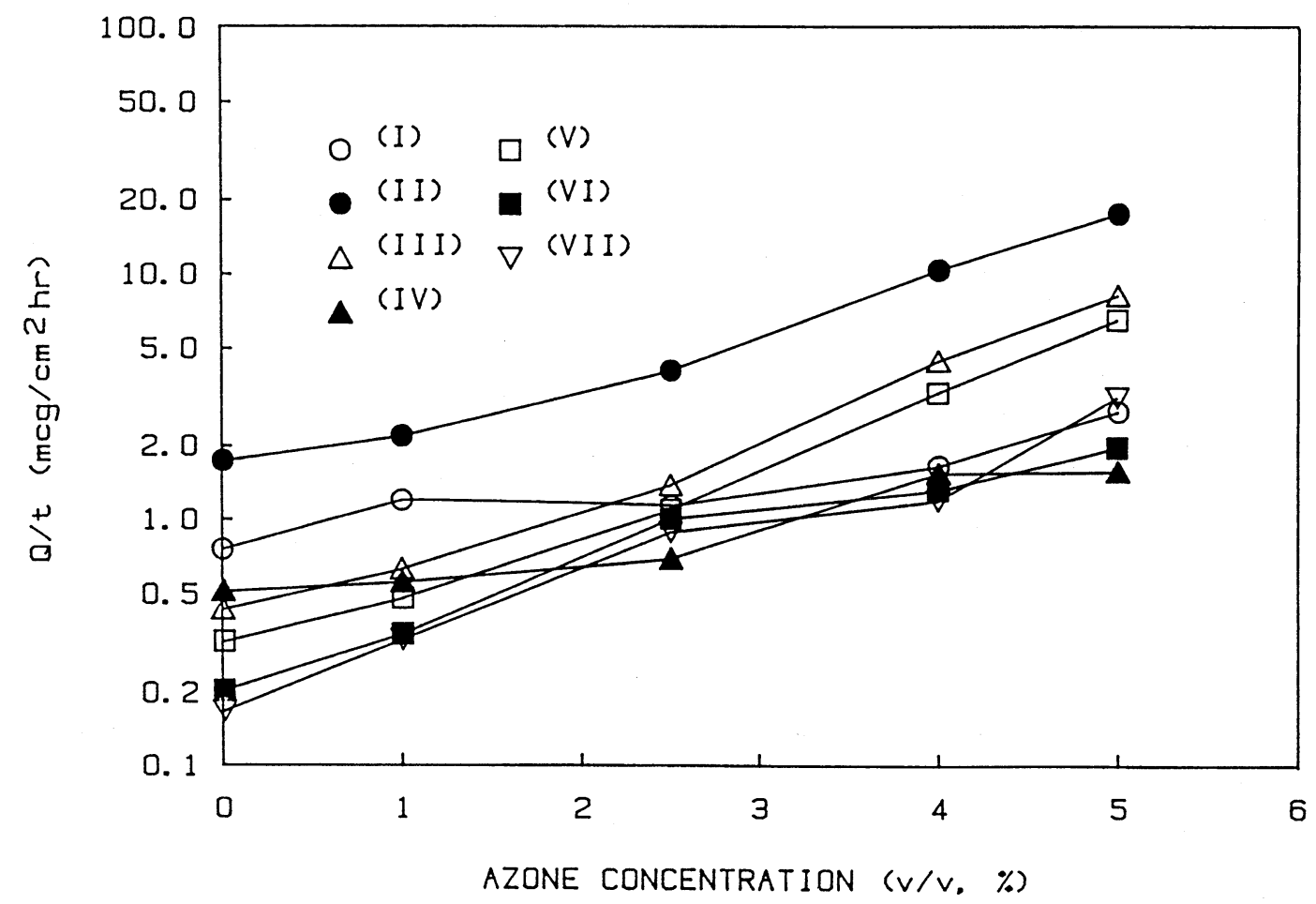

図 4.Progestins の皮膚透過速度(定常状態)におよぼす Azone 濃度の影響 薬物 key $(\mathrm{mcg}=\mu \mathrm{g})$ : (I) Progesterone, (II) Desoxycorticosterone, (III) $11 \alpha$-Hydroxyprogesterone, (IV) $17 \alpha$-Hydroxyprogesterone, (V) Corticosterone, (VI) $17 \alpha$-Hydroxy desoxy corticosterone, (VII) Hydrocortisone.

ロイド核）をもつ種々のプロゲスティンについて定常状 態透過速度におよぼす Azone 濃度の影響を図 4 に示 す。図から明らかなように透過速度は，もっとも親油性 の高いプロゲステロン以外, 約 10 倍程度 Azoneによ り增大した。さらにインタクトスキンと角質層を取除い た皮膚 (viable skin) の透過曲線を 2 層モデルで解析 し, 角質層内拡散係数とAzone 濃度の関係を図 5 に示 した．拡散係数は Azone 濃度の增大とともにやや增加 するが，その程度は，最大 2 倍程度であった。この結果 はAzoneによるプロゲスティンの皮膚透過促進が, 主 として角質層への分配の改善（角質層内溶解度の増大） に依存することを示す。

\section{4. 角質層ストリッピングの影響}

皮膚角質層は，10２0 層の扁平セルをブリックのよ うに種み重ね脂質で接着したようなブリックーモルタル 多層構造である ${ }^{5)}$ (図 6). 角質層は, 粘着テープを使っ
た数回のストリッピングで容易に取除かれる. 図 7 に定 常状態の透過速度におよぼすストリッピング回数の影響 を示す ${ }^{6)}$. (い゙れの薬物でもストリッピング初期, 透過 速度は急激に増大し, 約 15 回のストリッピングで最大 に達した後ほぼ一定に保たれた。これは, 15 回程度の ストリッピングで角質層が完全に取除かれることを示し ている．図中実線は 1 回のストリッピングで角質層が 1 $\mu \mathrm{m}$ (一層) はがれると仮定した場合の計算値である5). 皮膚に投薬後, 10 分および 30 分経過した際の角質層に 含まれるエストラディオールおよびビタミンCの濃度分 布を，ストリッピング回数の関数として図 8 に示す ${ }^{6)}$. エストラディオールおよびビタミンCは皮膚内にほとん ど結合しないことが確認されており7), 図8 の濃度分布 は, 角質層内を自由に拡散できる薬物濃度を示している. $20 \mu \mathrm{m}$ 程度の極めて薄い角質層のバリアー機能によっ て, 異分子の物理的侵入から生体を保護していることは 興味深い。皮膚（角質層内）で結合や分解のない薬物で は, 定常状態の透過速度が角質層のストリッピングから 


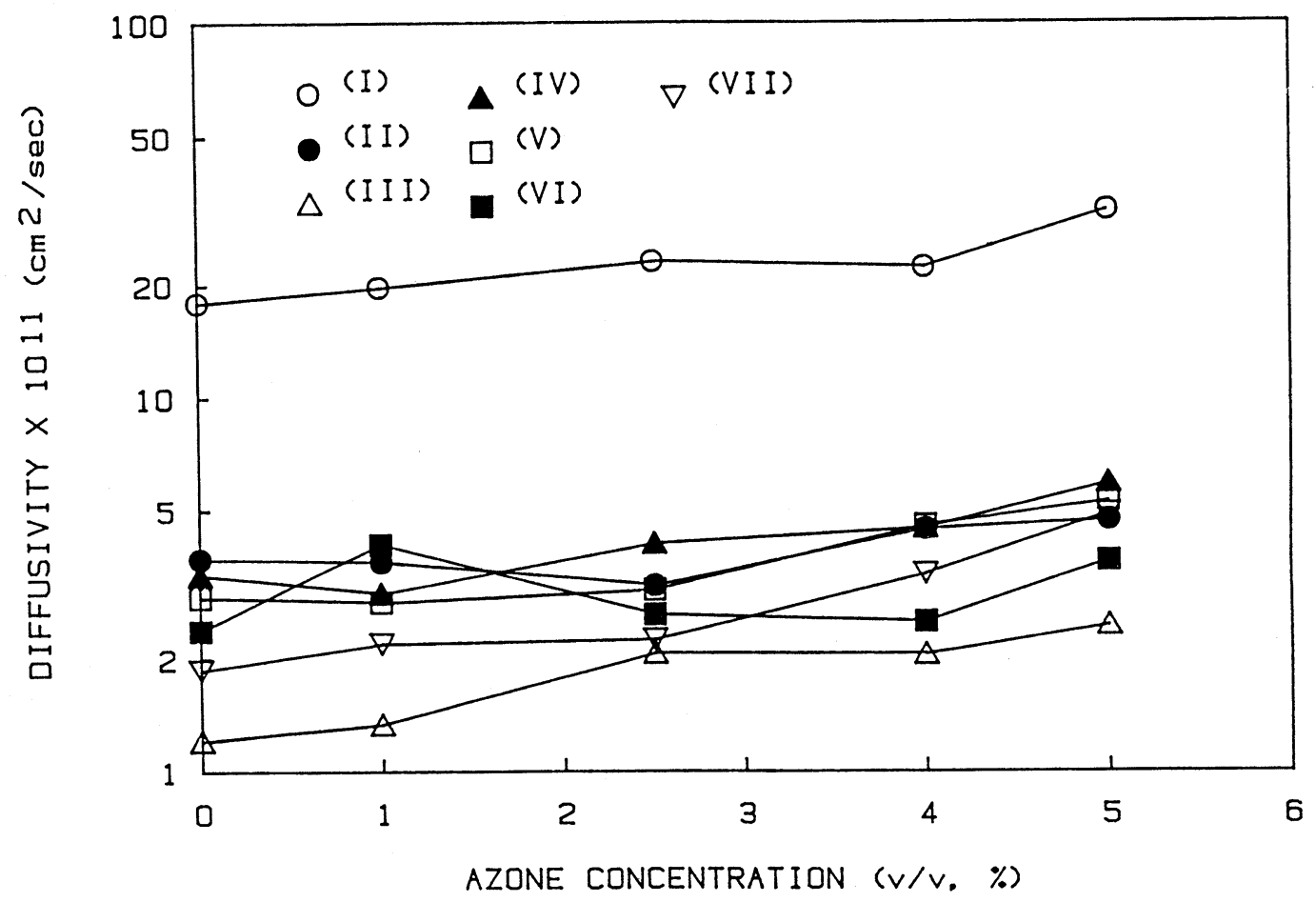

図 5. Progestins の角質層内拡散係数におよぼすAzone 濃度の影響 薬物の Key は図 4 の図説明に記述.

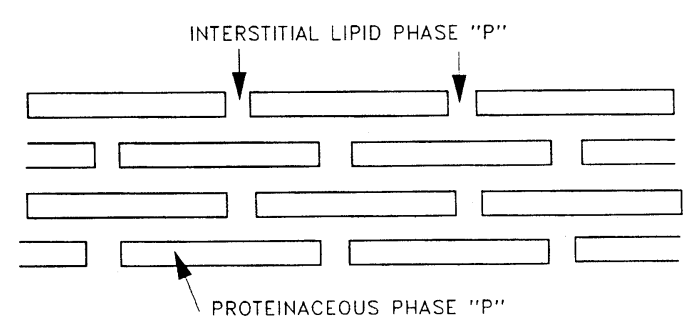

図 6. 理想的な角質層モデル (Brick-Mortar モデル)

求めた濃度分布にもとづいて推算できる ${ }^{6)}$.

\section{5. 透過速度におよぼす温度の影響}

一般に温度の上昇にともない薬物の皮膚透過速度は増 加する。これは, 皮膚内への薬物の溶解度および拡散係 数が温度とともに上昇することに起因する.ささらに，温 度上昇が角質層下部に発達している毛細管からの薬物の 取込みを促進することもあり, 温度上昇による透過速度 の促進は著しい。

皮膚透過におよぼす環境温度の影響を検討するため,

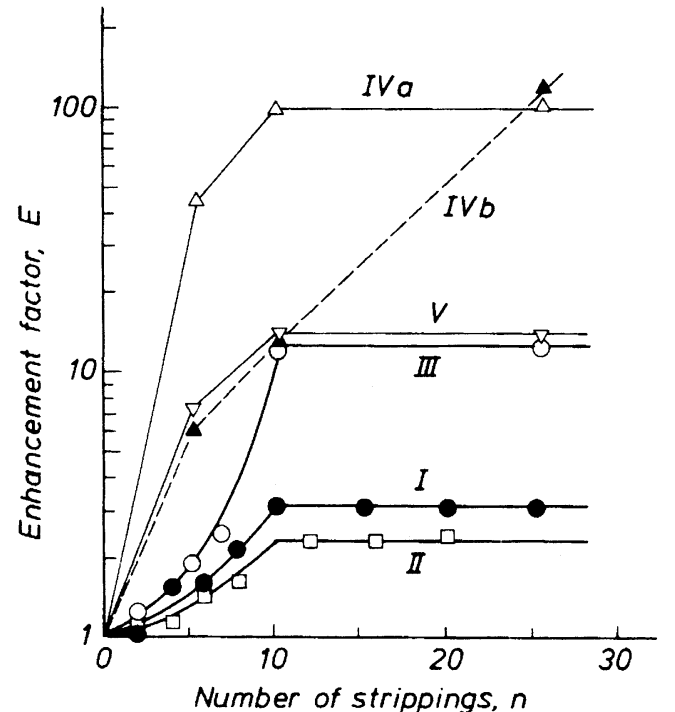

図 7. 定常状態皮膚透過速度におよぼす角質層又 トリッピングの影響

Enhancement factor : インタクトスキンの 透過速度を 1.0 とした場合のストリッピング による透過促進率. 薬物 Key : (I) nitroglycerin, (II) Progesterone, (III) verapamil, (IV) methanol, (V) phenol. 

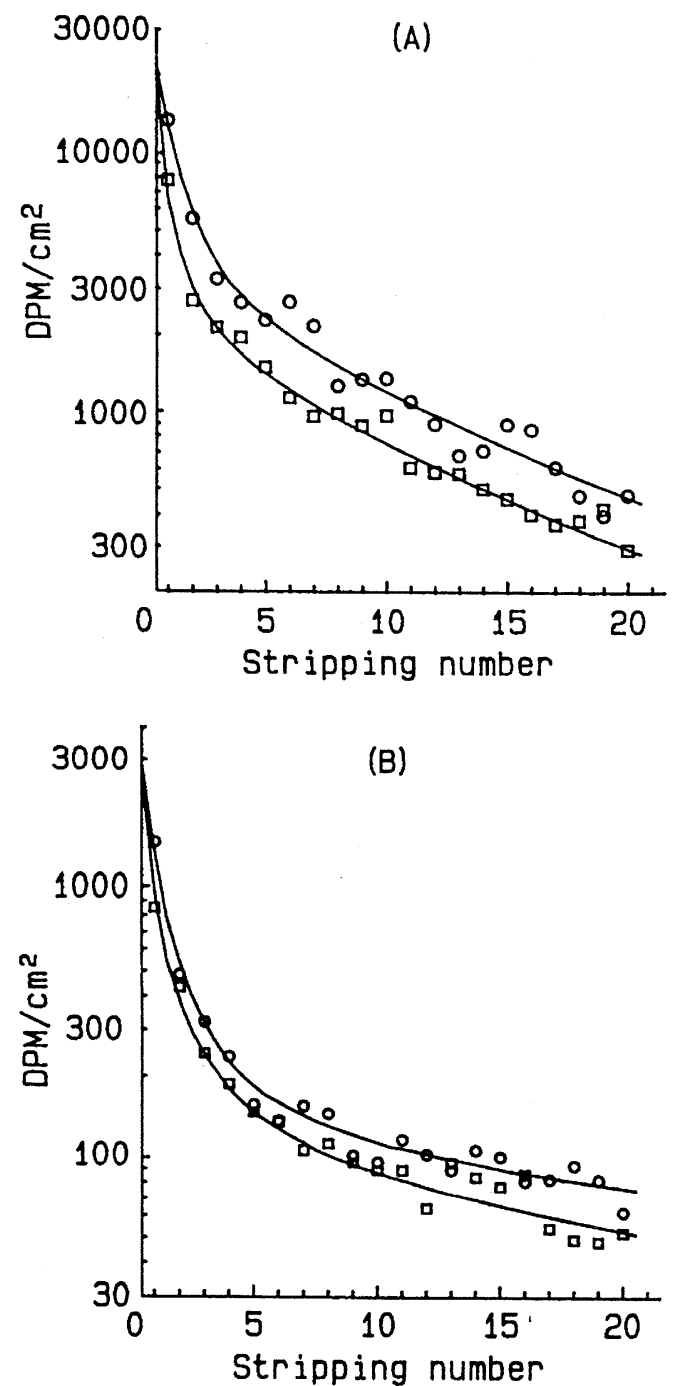

図 8. 皮膚(角質層) 表面に投薬後, 10 分および 30 分経過した際の角質層内薬物濃度分布 ${ }^{6)}$

(DPM=disintegrations per minute).

(A) Vitamin C, (B) Estradiol.

レセプター液温度を一定 $\left(37^{\circ} \mathrm{C}\right)$ に保ち, ドナー側温 度を種々変化させて透過実験（in vitro）を行った'). さらに，種々の定温系実験（ドナー側およびレセプター 側温度を一定に保った実験）での結果と比較した.イン タクトスキンならびに角質層を取除いたストリップスキ ンの透過曲線から, 種々の温度下での角質層およびスト リップスキン内の薬物の溶解度と拡散係数を定常状態透 過速度と時間遅れにもとづいて決定した ${ }^{8)}$. 図 9 および 図 10 にそれらの結果を示した. 図から明らかなように, 各種プロゲスティンの皮膚内溶解度ならびに拡散係数

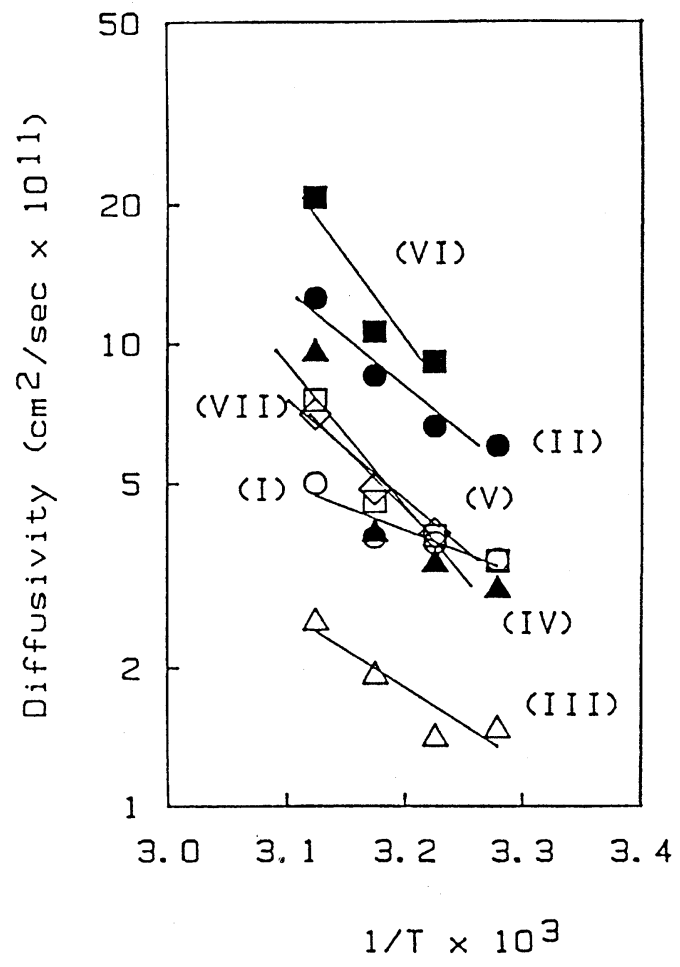

図 9. Progestins の角質層内拡散係数におよぼす 温度の影響 $\left(\mathrm{T}={ }^{\circ} \mathrm{K}\right)$

薬物 Key は図 4 の図説明に記述.

は,アレニウス型の関係式で表現できることを見出した.

\section{6. 透過速度におよぼす電場の影響}

皮膚に電場を与え, イオン化した薬物を透過促進させ るアプローチは, イオントフォレシス（イオン電気導入 法）と呼ばれ，小分子のみならずペプチド医薬について も有望視されている.アルギニンバゾプレッシンをモデ ル薬として使用した場合の in vitro 透過実験の一例を 図 11 に示す ${ }^{9)}$. 図中四印は電場を与えない場合の透過 曲線で口および○は, 2 種類の異なる電場モードにおけ る透過曲線である. 図から電場を与えない場合ほとんど 透過しない薬物が, 電場の導入によって十分透過するこ とが認められる. 図 12 はドナ一側薬物濃度を種々变化 させた場合の電場 $\left(0.47 \mathrm{~mA} / \mathrm{cm}^{2}\right)$ の影響を示す.ド ナー液濃度と透過量（透過速度）には単純な比例関係は 認められず，濃度の上昇にともない透過促進率が増大す るようである.なお図 11,12 中の実線は皮膚 2 層モデ ルによる計算值で, バゾブレッシンの場合, 電場に起因 


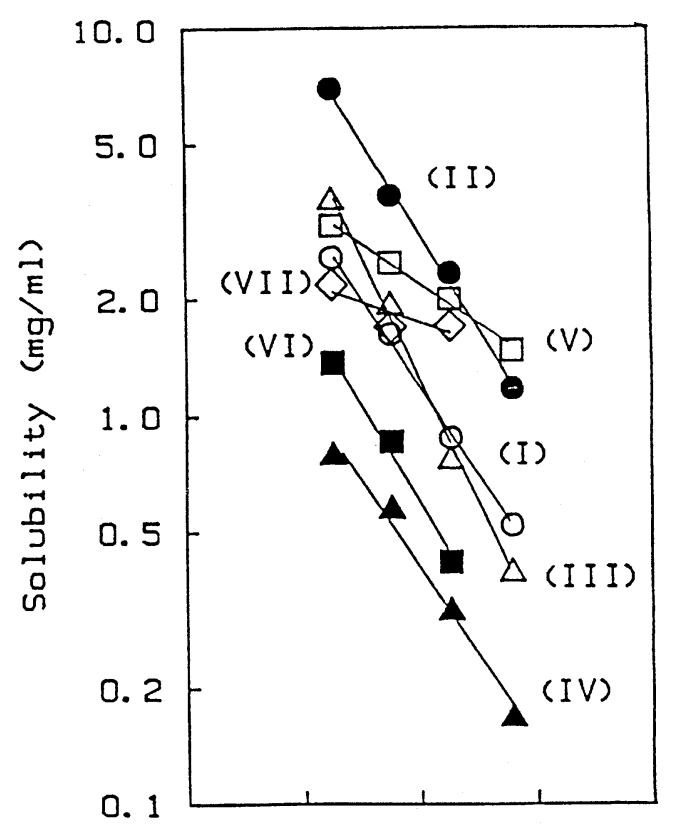

$\begin{array}{lllll}3.0 & 3.1 & 3.2 & 3.3 & 3.4\end{array}$

図 10. Progestins の角質層内溶解度におよぼす 温度の影響

薬物 Key は, 図 4 の Caption に記述 ( T $\left.={ }^{\circ} \mathrm{K}\right)$.

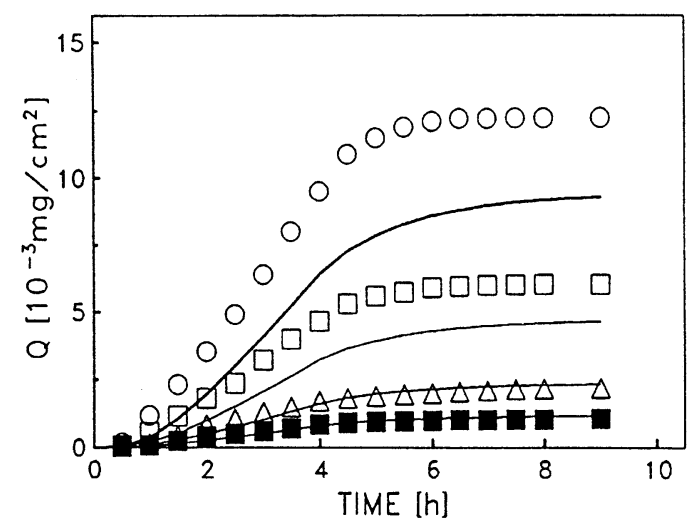

図 12. イオントフォレシスを利用した arginine vasopressin の経皮吸収におよぼすドナー 液濃度の影響 9

電流密度 : $0.47 \mathrm{~mA} / \mathrm{cm}^{2}, 4$ 時間連続通電 後 Shut off.

ドナー液薬物濃度 $(\mathrm{mg} / \mathrm{mL}):(\bigcirc) 0.100$, $(\square) 0.050,(\triangle) 0.025,(\square) 0.0125$.

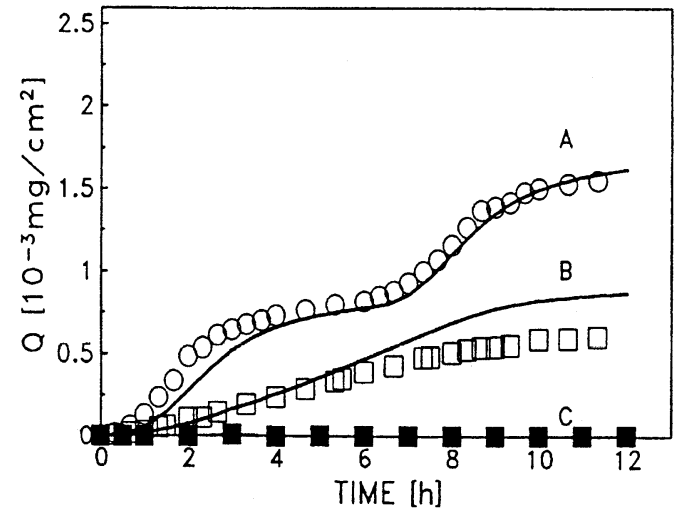

図 11.イオントフォレシスを利用した arginine vasopressin の経皮吸収 ${ }^{91}$

ドナー液薬物濃度 : $0.050 \mathrm{mg} / \mathrm{mL}$, 電流密 度 : $0.16 \mathrm{~mA} / \mathrm{cm}^{2}$, (A) 2 時間連続通電後 4 時間 Shut off の 2 回くり返し, (B) 10 分 間通電後 30 分間 Shut off の 12 回くり返し. (C) 通電なし.

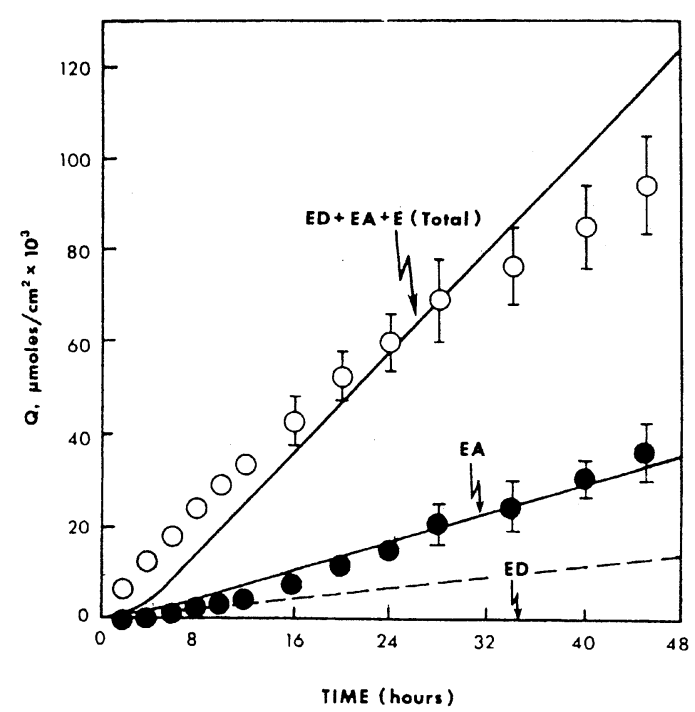

図 13. 皮膚内代謝 (分解) をともなう薬物（エス トラディオールエステル）の皮膚透過 ${ }^{32}$ ED : Estradiol-3, 17-diacetate, EA : Estradiol-17-acetate, E : estradiol. ……Estradiol（ドナー液）の透過（分解 のない場合).

する対流項が透過促進の重要な因子であることが見出さ れた(0). 


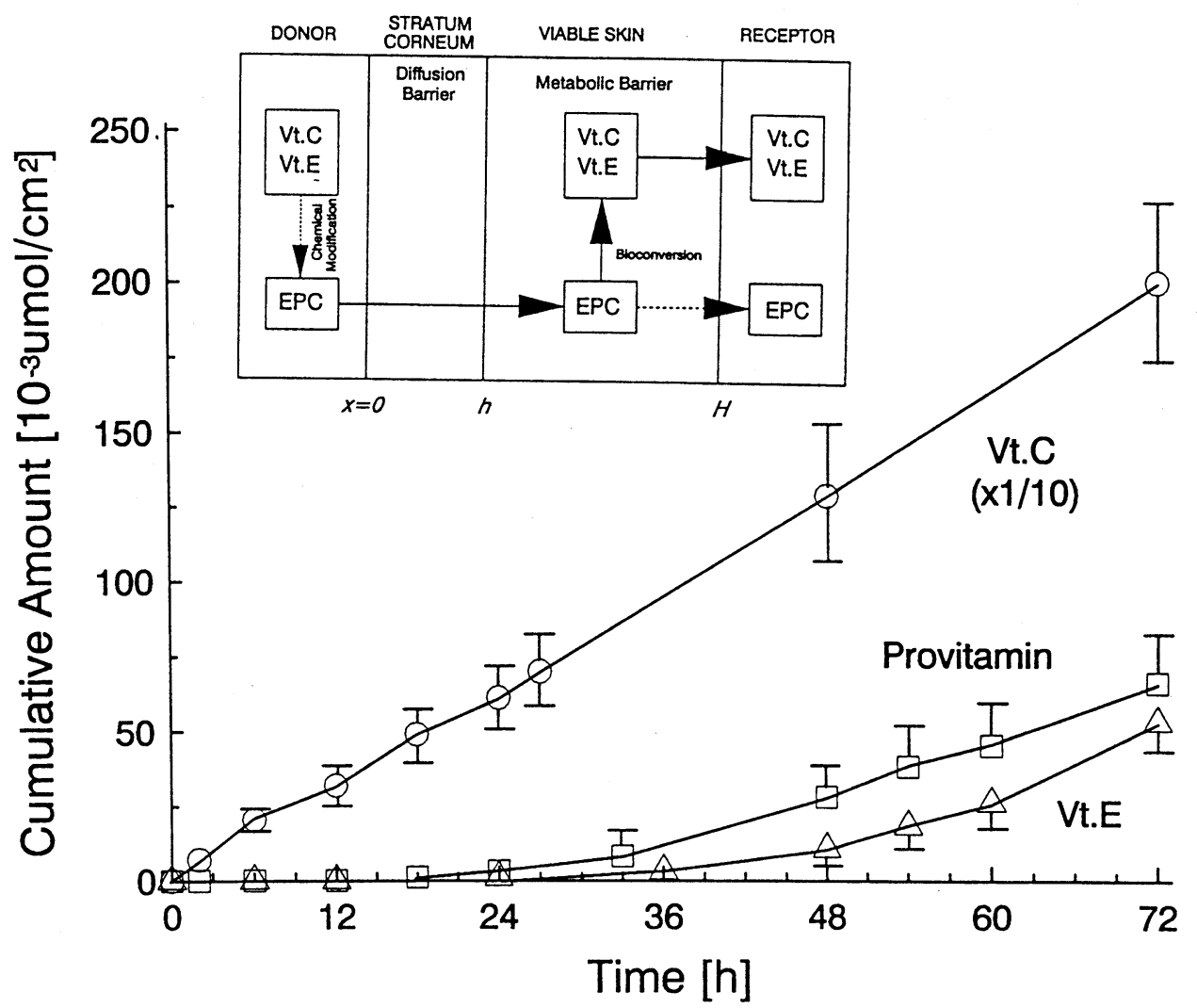

図 14. 皮膚内代謝をともなうプロビタミンの皮膚透過 $(\mathrm{u} \mathrm{mol}=\mu \mathrm{mol})$

プロビタミン: $\mathrm{EPC}-\mathrm{Na}$ Vt. C : ビタミン C Vt. E : ビタミン E.

ビタミン E はさらにE 代謝物に分解するので, みかけの透過量は, ビタミン Cにくらべ著しく少ない。

\section{7. 透過速度におよぼす超音波の影響}

イオントフォレシスは, 主としてイオン化した薬物に 有効な物理的透過促進法であるが, 超音波の利用（フォ ノフォレシス）はイオン化しない薬物にも有効である. さらに超音波は皮下 $5 \mathrm{~cm}$ 程度まで達するのに対し, 電 場は約 $1 \mathrm{~cm}$ 程度までしか到達しない.フォノフォレシ スは 1962 年, ハイドロコーチゾンの皮膚吸収に用いら れて以来 ${ }^{11)}$, 他の多くの薬物の透過促進に応用されて きた ${ }^{22}$. 臨床における操作条件を最適化できれば, 医師 の監視下で有効利用できる透過促進法である. 使用される 振動数はふつう $1 \mathrm{MHz}$ 程度, また強度は $1 \sim 2 \mathrm{~W} / \mathrm{cm}^{2}$ である，超音波による皮膚透過促進のメカニズムはまだ 十分理解されていない. キャビテーション, 局所的温度 上昇, 角質層の組織变化など複雑に関係していると考え られている。

\section{8. 薬物の皮膚代謝}

防御膜としての皮膚の機能は, 角質層による物理的防 御と下部上皮 (viable epidermis) での生化学的防御 （代謝）に分類される. 後者の薬物酵素分解を透過促進 に利用するアプローチをプロドラッグ法と呼び, 経皮治 療システムに利用される。その一例として皮膚内薬物 (エ ストラディオールエステル) 分解の結果を図 13 に示 $す^{(3)}$. 親油性の高いエストラディオールエステル (Estradiol diacetate : ED) は角質層に容易に分配した後, 下部上皮に達し, 中間体 (Estradiol acetate : EA)さ らに最終薬物エストラディオール $(\mathrm{E})$ に分解される. 図にはエストラディオールそのものの透過量も比較のた め示した．図からわかるように，エストラディオールの 透過量はプロドラッグ (ED) を用いることにより約 7 倍促進される. 図 14 はプロビタミン (EPC) のビタミ

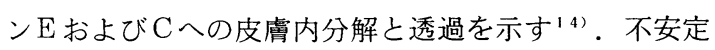




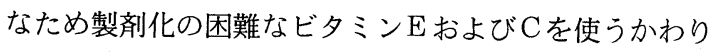

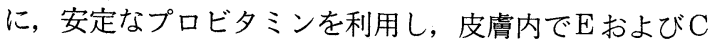
に変換するアプローチである。この例ではビタミン $\mathrm{E}$ さらにE 代謝物（例えば $\alpha$-Tocopherol quinone）に 変換されることが認められた ${ }^{15}$.

\section{9. おわりに}

薬物を皮膚から全身の標的組織へ送達するための経皮 治療システムを開発する際, 透過促進として検討すべき 諸因子と, それらの透過速度におよぼす影響を簡単に述 ベた，皮膚に刺激や感作を引き起こさず, 治療効果を期 待できる程度に薬物を透過させることは極めて困難であ る. しかし種々の透過促進法を組合せることにより最適 な透過促進が実現される可能性は大きい。

\section{文献}

1) K. Tojo, "Design and calibration of in vitro permeation apparatus", in "Transdermal controlled systemic medications," Edited by $\mathrm{Y}$. W. Chien, chapt. 6, Marcel Dekker Inc., New York, pp 127-158, 1986.

2) K. Tojo, C.C. Chiang, Y.W. Chien, "Effect of azone on skin permeation of progesterone analogs and possible mechanism of enhancement", 1st AAPS National Mtg., Washington D. C. November 1986.

3) K. Tojo, C. C.Chiang, Y.W. Chien, "Influence of donor solution upon skin permeation of drugs", J. Chem. Eng. Japan, 19, 153-155 (1986)

4) K. Tojo, "Random brick model for drug transport across stratum corneum", J. Pharm. Sci., 76, 889-891 (1987)
膜 (MEMBRANE), Vol. 15 No. 6 (1990) 303

5) K. Tojo, C. C. Chiang, P. R. Keshary, Y. W. Chien, "Effect of stepwise skin stripping on drug permeation”, J. Chem. Eng. Japan, 21, 544-546 (1988)

6) K. Tojo, A.R.C. Lee, "A method for predicting steady-state rate of skin penetration in vivo", J. Invest. Dermatol., 92, 105-108 (1989)

7) K. Tojo, C.C.Chiang, U. Doshi, Y. W. Chien, "Stratum corneum reservoir capacity affecting dynamics of transdermal drug delivery", Drug Dev. Ind. Pharm. 14, 561-572 (1988)

8) K. Tojo, C. C. Chiang, Y. W. Chien, "Drug permeation across the skin : Effect of penetrant hydrophilicity", J. Pharm. Sci., 76, 123126 (1987)

9) K. Tojo, P. Lelawongs, Y. W. Chien, "A dynamic model for iontophoretic transdermal delivery of peptides", Proceed. Intern. Symp. Control. Rel. Bioact. Mater., 16, 452-453(1989)

10) P. Lelawongs, "Transdermal iontophoretic delivery of arginine vasopressin", Ph. D. Thesis, Rutgers University, January 1990.

11) T. Griffin, J. Touchstone, Proc. Soc., Exp. Biol. Med., 109, 461-465 (1962)

12) P. Tyle, P. Agrawala, "Drug delivery by phonophoresis", Pharm. Res., 6, 355-361 (1989)

13) K. Tojo, K.H. Valia, G. Chotani, Y.W. Chien, "Long-term permeation kinetics of estradiol. IV", Drug Dev. Ind. Pharm., 11, 1195-1212 (1985)

14) K. Tojo, A. R. C. Lee, "Bioconversion of provitamin to vitamins $\mathrm{C}$ and $\mathrm{E}$ in skin", J. Soc. Cos. Chem., 38, 333-339 (1987)

15) A. R. C. Lee, "Percutaneous absorption and bioconversion of provitamin for vitamin $\mathrm{C}$ and E, Ph. D. Thesis", Rutgers University, May 1990.

（受付 1990 年 10 月 23 日） 